\title{
Crocodiles, sharks and turtles: the urban geo-palaeontological heritage of Cagliari (Italy)
}

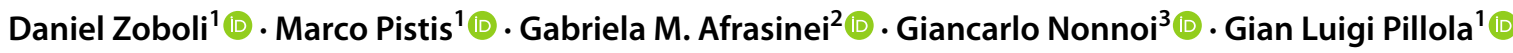

Received: 6 October 2020 / Accepted: 25 May 2021 / Published online: 6 June 2021

(c) The Author(s) 2021

\begin{abstract}
In this paper, we report on the first project on the promotion of urban geoheritage in Cagliari, the capital of the Autonomous Region of Sardinia (Italy). We briefly address the history of geo-palaeontological research in the city area and outline the main phases of development in the history of Cagliari's geo-palaeontological museum. Geotourism is an efficient method of bringing geosciences to a wider audience. For this project, we compiled a geoitinerary of the main lithotypes and fossils present within the urban territory. Miocene lithotypes are the most important materials in the edification of the Cagliari's old town, and in the past, the quarrying activity favoured the geology knowledge of the area. The presence of abandoned quarries and natural outcrops in parks, public gardens, on the nearby coastline, and also of fossils exposed in ashlars of historic buildings, made Cagliari an excellent example to valorise the geo-palaeontological heritage using geotourism. This project showcases the importance of knowledge transfer and non-technical communication methods by converting highly technical aspects into accessible and engaging information dissemination to a wide range of audience types, including non-specialised ones.
\end{abstract}

Keywords Geoconservation $\cdot$ Geological heritage $\cdot$ Geotourism $\cdot$ Teaching $\cdot$ Museography $\cdot$ Sardinia

\section{Introduction}

Cagliari is the capital of the island of Sardinia, an autonomous region of Italy. Its metropolitan city (including Cagliari and 16 other nearby municipalities) has about 430,000 inhabitants representing the most densely populated centre of the region. The city is located along the southern coast of Sardinia, in the centre of the Golfo degli Angeli (Fig. 1). The territory of Cagliari has been populated since the Neolithic period, but the greatest development occurred only during the Phoenician-Punic-Roman period. It was during this period, and in subsequent centuries, that outcrops of Miocene sedimentary succession were exploited for the

Daniel Zobol

danielc.zoboli@unica.it

1 Dipartimento di Scienze Chimiche e Geologiche, University of Cagliari, Cittadella Universitaria SS 554, 09042 Monserrato, CA, Italy

2 School of Surveying and Construction Management, College of Engineering and Built Environment, Technological University of Dublin, Bolton Street, Dublin, Ireland

3 Dipartimento di Lettere, Lingue e Beni Culturali, University of Cagliari, Via Is Mirrionis 1, 09123 Cagliari, CA, Italy extraction of limestone for construction. During the past two centuries quarrying activity has unintentionally contributed to an increase in the geo-palaeontological knowledge of the territory, where early geologists were facilitated in their research by the abundance of quarries and natural outcrops. These pioneers of geology and palaeontology in Sardinia, through their numerous works, made a fundamental contribution to the collections currently housed at the Sardinian Museum of Geology and Palaeontology (Museo Sardo di Geologia e Paleontologia Domenico Lovisato) of the University of Cagliari (Comaschi Caria 1979, 1986). The museum archives and the geo-palaeontological features of the urban territory allowed the creation of the project "Coccodrilli, squali e tartarughe, storie di fossili a Cagliari e nell' area urbana" (Crocodiles, sharks and turtles, tales of fossils of the greater Cagliari area, acronym CST) which aims to disclose the region's rich geoheritage and urban geotourism potential.

Geotourism is a type of tourism aiming at the promotion and safeguarding of natural heritage, with geology, palaeontology and geomorphology as its main elements, in association with knowledge of a given environment as a whole, including biosphere and environmental education, as well as aspects related to the socio-economic development of 


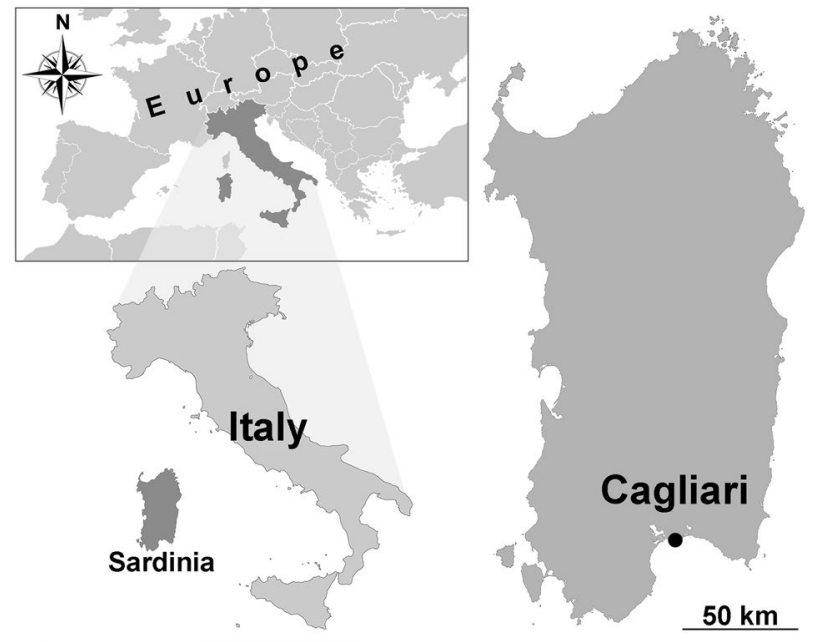

Fig. 1 Geographical location of Cagliari (Sardinia, Italy)

local populations (Hose 2000, 2008; Del Lama et al. 2015; Berrocal-Casero et al. 2018).

Globally, Italy is recognised as a tourist destination for its artistic, historic and archaeological heritage. However, Italy's natural heritage is equally rich and provides important opportunities for socio-economic development in coastal and mountainous areas (Italy's coastline is about $7900 \mathrm{~km}$ ). In recent times, geotourism is thriving in Italy, and numerous initiatives linked to geotourism are present or in development (Santangelo et al. 2015; Giordano et al. 2016; Magliulo et al. 2020; Todaro 2019; Venturini and Mariotto 2020; Liso et al. 2020). Despite its great geological heritage, this type of tourism is still yet to be developed in Sardinia, with a few isolated cases in the rural areas of the centre of the island (Sanciu and Zoboli 2018).

The aim of this paper is to communicate the urban geoheritage of Cagliari, by illustrating a geo-palaeontological itinerary of the region that may help to showcase its high geological value and geotourism potential. This geoitinerary includes natural and anthropogenic Miocene outcrops situated in public gardens and parks, as well as exploring the fossil content in ashlar masonry visible in buildings within Cagliari's old town district (Castello neighbourhood).

\section{Geological and Palaeontological Settings}

The Cagliari area is characterised by a marine sedimentary succession referred to as middle-late Miocene (middle Langhian-Messinian). The succession has been divided into three stratigraphic formations from earliest to latest: Argille di Fangario Fm., Arenarie di Pirri Fm. and Calcari di Cagliari Fm. These formations are well exposed and represented by extensive outcrops especially in the various hills and parks of the city, and along the coastline (Fig. 2a-c).

The succession starts with the Argille di Fangario Formation. This formation outcrops discontinuously in the NW environs of the city and is represented principally by grey clays and sandy-clays. Sand levels become more frequent at the top of the formation. The palaeontological content is very rich; invertebrates are represented by foraminifera, ostracods, bryozoans, brachiopods, corals, molluscs and echinoids (Spano and Barca 2002). Furthermore, isolated shark and crocodile teeth are present (Del Vecchio 1921; Comaschi Caria 1973). The fossil associations indicate a middle Langhian-early Serravallian age (Cherchi 1974).

The Miocene succession continues with the Arenarie di Pirri Formation. This formation is characterised by an alternation of sandstones and sands with intercalation of conglomerate layers. These outcrops are also located in the NE periphery of Cagliari, but especially to the SE of the urban area where the formation is the most extensive lithological substrate (Cherchi 1974). Numerous but not extensive outcrops are present within the urban districts of Is Mirrionis, San Michele, Sant'Avendrace, Sa Duchessa, San Benedetto, Monte Claro and Monte Urpinu. The palaeontological content is primarily represented by foraminifera and molluscs that indicate a Serravallian age (Cherchi 1974; Leone et al. 1992).

A great part of the current urban area of Cagliari, including many historical buildings in the old town area, was built using Miocene lithotypes of the Calcari di Cagliari Formation (Gandolfi and Porcu 1967; Cherchi 1974). Since historical times, the areas of Is Mirrionis, Tuvixeddu/Tuvumannu hills and Sant'Avendrace neighbourhood have been intensively quarried for building materials (Columbu et al. 2017). This carbonate succession is currently well exposed along the coastline and in numerous hills and parks of the city. The Calcari di Cagliari $\mathrm{Fm}$. is represented by three main lithofacies which are from bottom to top: "Pietra Cantone", "Tramezzario" and "Pietra Forte". These were the names given by quarrymen and are informally adopted into official geological maps (Barca et al. 2005). The "Pietra Cantone" is represented by stratified yellow marly-arenaceous limestone locally intensely bioturbated. The "Tramezzario" is composed of whitish calcarenites, locally marly with abundant bioclastic components. Furthermore, the lithofacies shows widespread phenomena of synsedimentary breccias, slumpings, erosional surfaces and faulting. The "Pietra Forte" consists of massive coarse and biostromal limestone (Barca et al. 2005). The Calcari di Cagliari Fm. is considered to be the late Miocene in age (Cherchi 1974; Barca et al. 2005), with the Tortonian-Messinian boundary tentatively placed within the upper part of the "Pietra Cantone" lithofacies (Georgalis et al. 2017). The palaeontological content of 

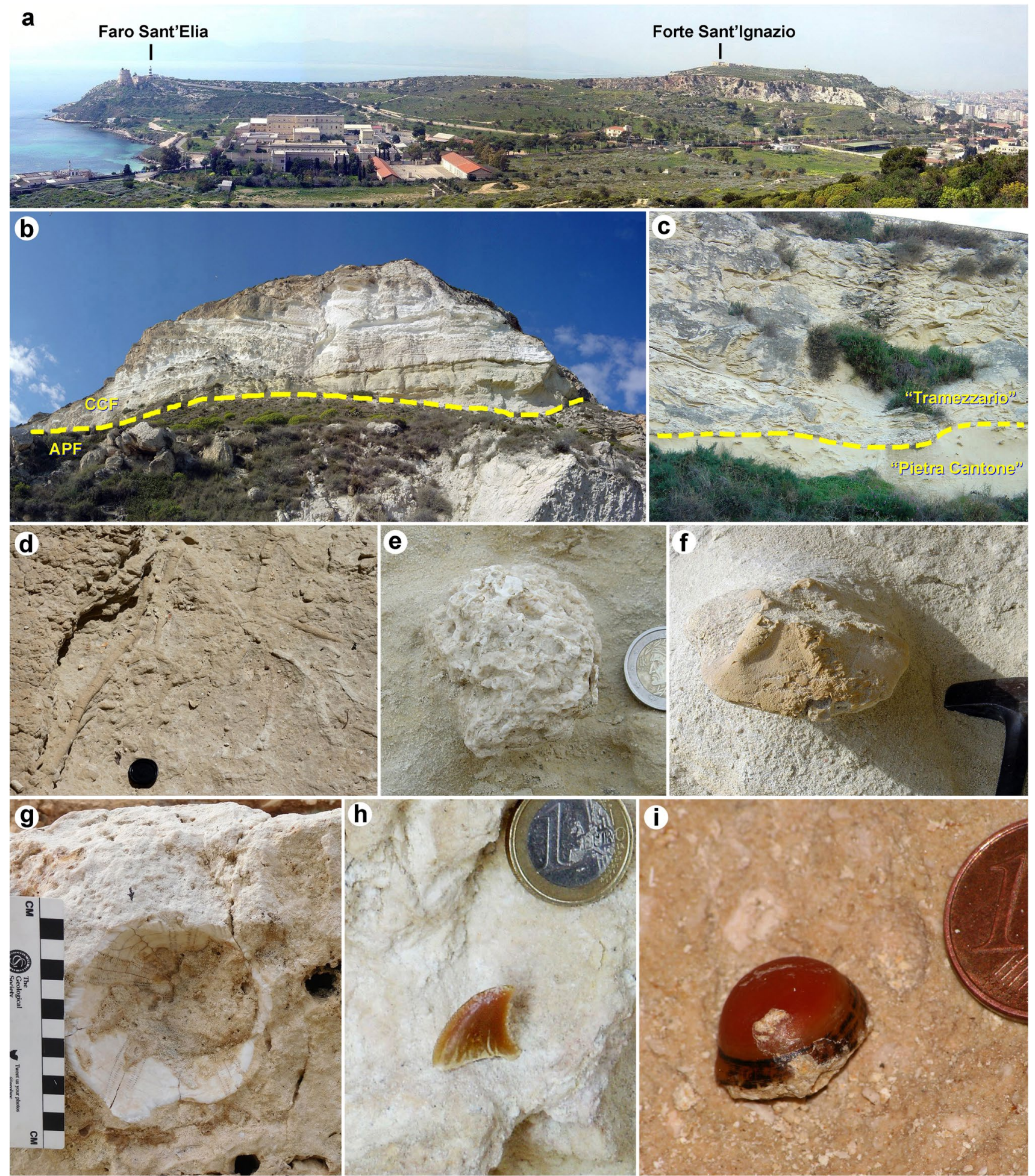

Fig. 2 a Panoramic view from Monte Sant'Elia in direction of Faro Sant'Elia - Forte Sant'Ignazio, b Arenarie di Pirri Fm. (APF) - Calcari di Cagliari Fm. (CCF) boundary, cliff located SW of Monte Sant'Elia, c "Pietra Cantone" - "Tramezzario" boundary, Calcari di Cagliari Fm., NW flank of Colle San Michele (route 2-9th stop), d ichnofossils, Calamosca (Capo Sant'Elia, route 3-4th stop), "Tramezzario" lithofacies, e red algae (Lithothamnion sp.), Faro Sant'Elia
(Capo Sant'Elia, route 3-5th stop), "Tramezzario" lithofacies, $\mathbf{f}$ echinoid (Clypeaster sp.), Sella del Diavolo (Capo Sant'Elia), Arenarie di Pirri Fm., g undetermined echinoid, Calamosca (Capo Sant'Elia, route 3-4th stop) "Tramezzario" lithofacies, h shark tooth, Cala Fighera (Capo Sant'Elia, route 3-3rd stop), "Tramezzario" lithofacies, i fish tooth (Sparidae indet.), Cala Fighera (Capo Sant'Elia, 3rd stop of route 3), "Tramezzario" lithofacies 
the Calcari di Cagliari Fm. is very diversified (Fig. 2d-i). Invertebrates and ichnofossils are very abundant with a predominance of molluscs and echinoids (Lovisato 1902; Comaschi Caria, 1958, 1972, 1986). About vertebrates (Fig. 3), a large number of fish remains, and in particular shark teeth, were collected in all lithofacies (Comaschi Caria 1973). Turtle, crocodile, cetacean and sirenian remains were also collected in the "Pietra Cantone" and "Tramezzario" lithofacies (Gennari 1868; Capellini 1886, 1899; Vigliarolo 1893; Del Vecchio 1921; Comaschi Caria 1959a). Isolated crocodile teeth, referred to Crocodylia indet., were collected in different localities of Cagliari: Tuvumannu, Bonaria, Montixeddu di Bonaria - Cava Timon, Cimitero Monumentale di Bonaria and Is Mirrionis - Piazza d'Armi (Del Vecchio 1921; Zoboli et al. 2019). Remains of a single specimen attribuited to Tomistoma calaritanum Capellini 1890a, b were recovered at Piazza d'Armi (Gennari 1868; Capellini 1890a, b). Soft-shell turtles (Pan-Trionychine indet.) were collected in the Is Mirrions - Piazza d'Armi area (Portis 1901a; Comaschi Caria 1959a; Georgalis et al. 2017), while an internal mould of a marine turtle shell (Cheloniidae indet.) was found in the Sant'Avendrace neighbourhood (Comaschi Caria 1959a). Cetaceans are represented by a poorly preserved dolphin and whale remains collected at Tuvumannu and Colle San Michele respectively (Vigliarolo 1893; Capellini 1899).

In addition to the Miocene succession, continental and marine Quaternary deposits are present. Quaternary marine deposits are represented by the Calamosca sub-synthem that outcrops mainly along the coast and especially in Calamosca (Barca et al. 2005). The marine sequence lies on an erosional surface at $2 \mathrm{~m}$ above the current sea level and is represented by littoral sediments such as beach sandstones and conglomerates and backshore sandstones (Fig. 4a, b). The palaeontological content is represented by the "Senegalese fauna" assemblage (e.g. the mollusca Persististrombus latus, Conus ermineus, Patella ferruginea and Mytilus galloprovincialis), which is characteristic of the last interglacial MIS 5e (Tyrrhenian Stage, in the Italian Mediterranean Marine Stages) (Issel 1914; Ulzega and Ozer 1980) (Fig. 4c). Quaternary continental deposits are generally represented by alluvial sediment bodies of the Late Pleistocene (Portoscuso subsynthem) and Holocene age (Barca et al. 2005). Moreover, fracture fillings on Miocene lithotypes contain Pleistocene bone breccias were identified in the Monreale di Bonaria area (Lamarmora 1857). These bone breccias are not currently visible as they were exploited by quarry activity and subsequently engulfed by urban development.

Currently, fossils and lithological samples representative of the Neogene and Quaternary successions of the Cagliari area are housed in the Sardinian Museum of Geology and Palaeontology Domenico Lovisato (Museo Sardo di Geologia e Paleontologia "Domenico Lovisato", MDLCA).

\section{The Museo Sardo di Geologia e Paleontologia Domenico Lovisato}

\section{Historical Background}

The MDLCA is located on the ground floor at the former Department of Chemical and Geological Sciences (Dipartimento di Scienze Chimiche e Geologiche) in the Sa Duchessa neighbourhood. The museum hosts the original collections of the Viceroy of Sardinia Carlo Felice di Savoia (1765-1831) and includes specimens of minerals, rocks, fossils, zoological finds, herbs, anatomical waxes and archaeological artefacts. In 1806, the materials were transferred from Royal Palace (Palazzo Regio) to Belgrano Palace (Palazzo Belgrano), current headquarters of the University of Cagliari, and arranged in various exhibition halls. In subsequent decades, the collection has been expanded with additional rock and fossil samples collected throughout Sardinia by General Alberto Lamarmora (1789-1863). In 1859, the natural history collections were displayed separately in the Museum of Natural History (Museo di Storia Naturale), while in 1864, the geo-palaeontological and mineralogical collections were renamed the Royal Museum of Mineralogy and Geology (Regio Museo di Mineralogia e Geologia). In 1884, Domenico Lovisato (1842-1916) arrived in Sardinia as Professor of Mineralogy, contributing to increasing the museum collection with a considerable number of fossils. In 1922, the collection of the Royal Museum of Mineralogy and Geology was divided into two museums: the Museum of Mineralogy Leonardo De Pruner (Museo di Mineralogia Leonardo De Pruner) and the Sardinian Museum of Geology and Palaeontology Domenico Lovisato (Museo Sardo di Geologia e Paleontologia Domenico Lovisato). During World War II, in February 1943, Cagliari was involved in an Anglo-American bombing raid that damaged Palazzo Belgrano and destroyed part of the collection. The surviving materials, which had been placed into the basement of the Palazzo Belgrano for protection, were subsequently moved to the village of Ghilarza in central Sardinia. In the 1950 s, the collections of the two museums were moved to their current location as the Institute of Mineralogy (Istituto di Mineralogia) and Institute of Geology (Istituto di Geologia) of Cagliari (former Dipartimento di Scienze Chimiche e Geologiche) (Comaschi Caria 1979).

\section{Neogene and Quaternary Collections}

Several rock and fossil collections are housed at the MDLCA, which have been acquired by successive palaeontologists from the University of Cagliari. 


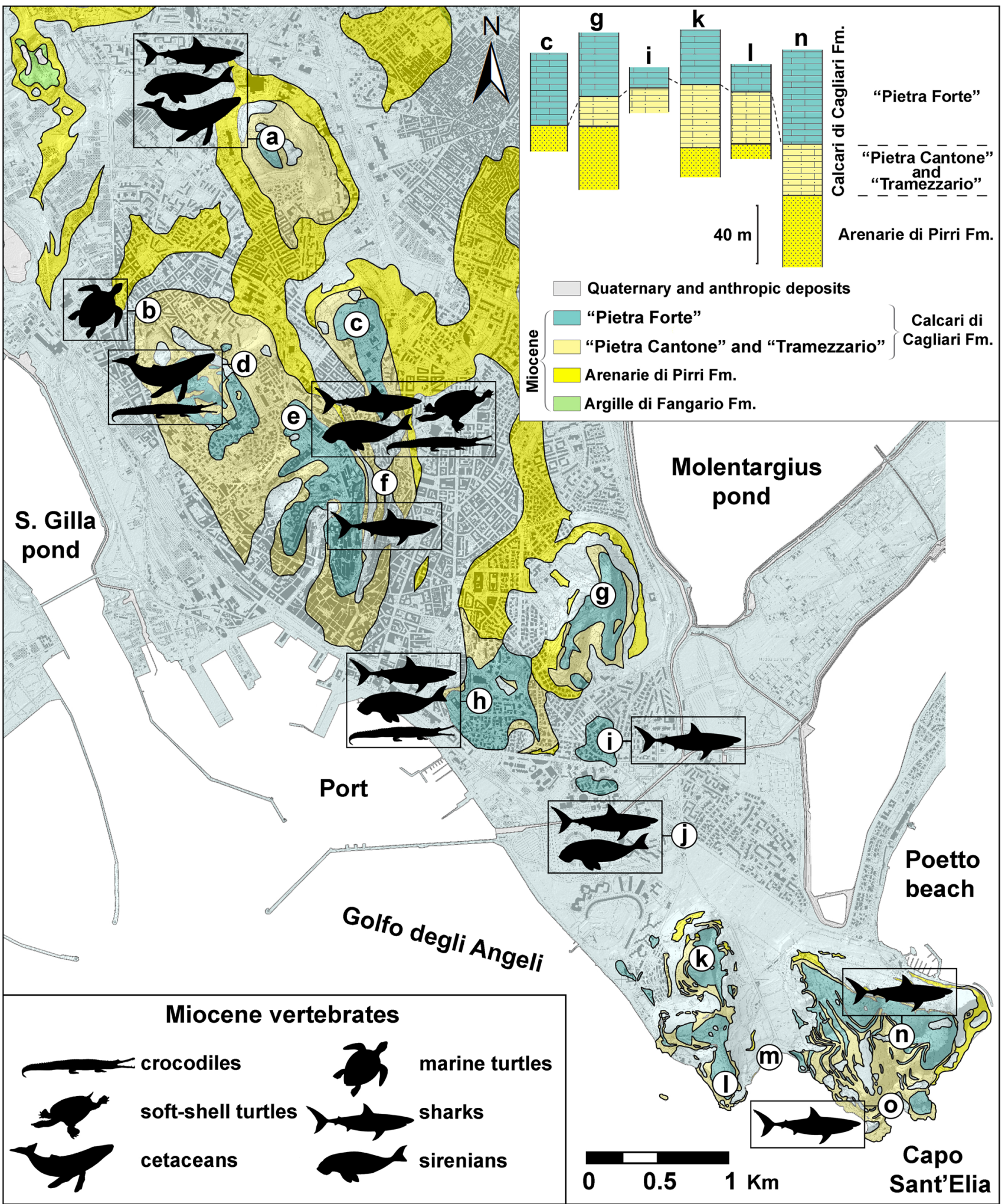

Fig. 3 Lithological map of the Cagliari area, stratigraphic columns of the Miocene marine sequence and main fossil sites with vertebrate remains, a Colle San Michele, b Sant'Avendrace, c Monte Claro, d Tuvumannu (Monte della Pace), e Piazza d'Armi - Is Mirrionis, f Giardini Pubblici - La Vega, g Monte Urpinu, h Monreale di Bonaria (encluding the Monumental Cemetery), i Monte Mixi, j San Bartolomeo, k Forte Sant'Ignazio, I Faro Sant'Elia, m Calamosca, n Monte Sant'Elia, o Cala Fighera. Stratigraphic columns redrawing after Pecorini and Pomesano Cherchi 1969 


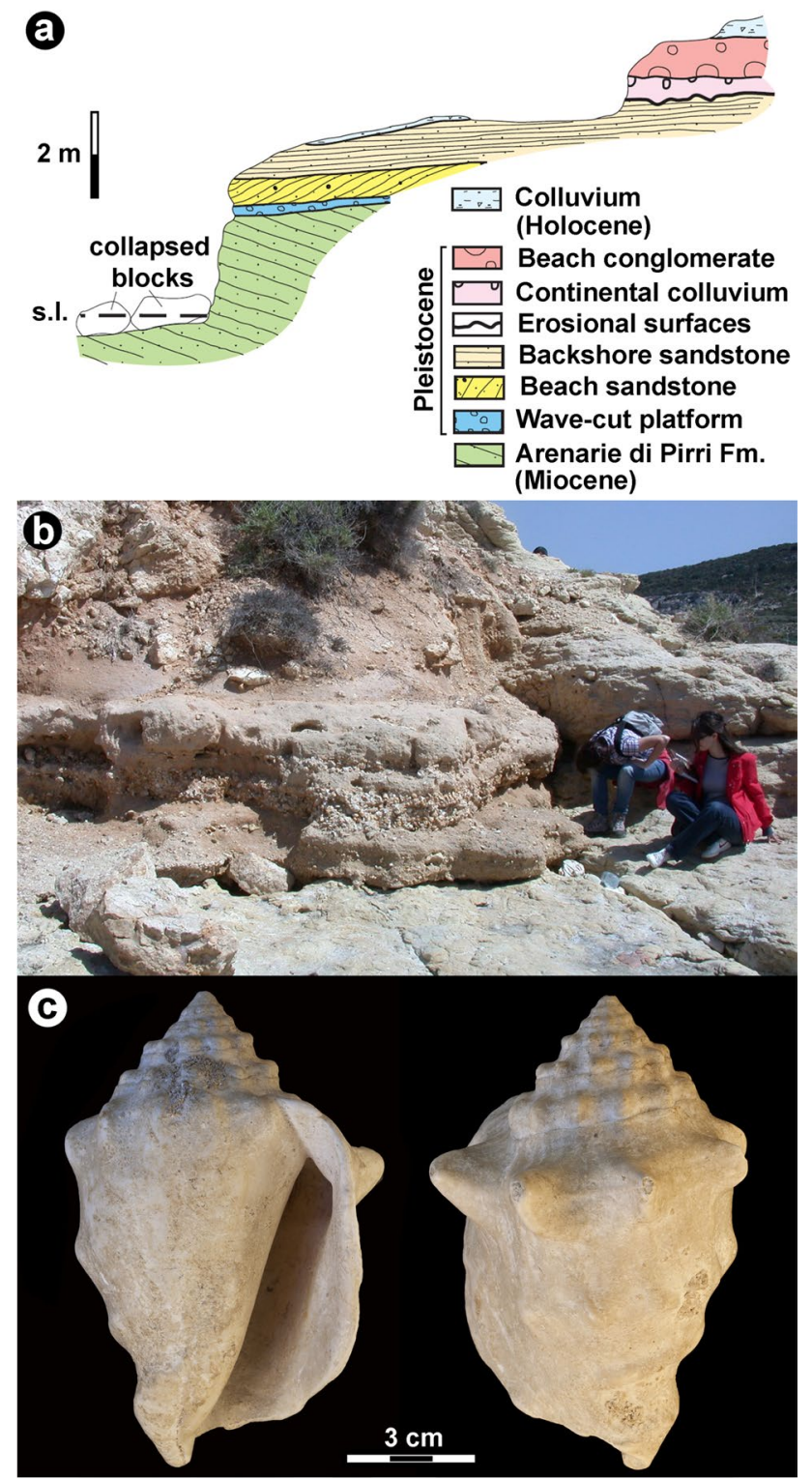

Fig. 4 a Stratigraphic section of the Tyrrhenian succession at Calamosca (modified after Ulzega and Ozer 1980), b Tyrrhenian fossiliferous conglomerate unconformably above the Miocene succession at Calamosca (route 3-4th stop), $\mathbf{c}$ the gastropod Persististrombus latus (Gmelin 1791), Tyrrhenian of Calamosca, MDLCA

Alberto Lamarmora (Fig. 5a) contributed enormously to our knowledge of Sardinian geological history (Lamarmora 1857). During his tenure on the island, he collected a considerable number of rock and fossil samples, a selection of which are currently housed at MDLCA (Fig. 5c). In particular, Lamarmora collected numerous vertebrate remains in the Pleistocene bone breccias at Monreale di Bonaria (Fig. 5b), which helped to establish the new taxon Cynotherium sardous Studiati, 1857 (in Lamarmora 1857), an endemic and common dog which was found in Sardinia and Corsica during the Middle-Late Pleistocene (Zoboli and Pillola 2016, 2017).

The Lovisato's Collection presents a higher number of samples that include Miocene fossils found across Sardinia, but the Cagliari area in particular. These fossils are represented by plant remains, marine invertebrate (mainly echinoids) and vertebrates (fish, reptiles and mammals). Lovisato (Fig. 6a) principally collected fossils during the period in which quarry extraction was active. He collected invertebrates (echinoid fauna) from the hills surrounding Cagliari (Lovisato 1902, 1915a, b). Regarding fossil vertebrates, he limited himself to collecting fish and crocodile teeth, as well as turtle and marine mammal remains (Fig. 6b). These were sent to Bologna and Turin to be studied by Alessandro Portis (1853-1931) and Giovanni Capellini (1833-1922) respectively (Capellini 1886, 1899; Lovisato 1892; Portis 1901a, b). Lovisato also collected Pleistocene molluscs at Capo Sant'Elia, which he sent to Arturo Issel (1842-1922) who established the Tyrrhenian Stage based on a geo-palaeontological piece of evidence along the coastline of Cagliari, with its type section at Calamosca (Issel 1914).

Between the 1950s and 1970s, MDLCA acquired new Miocene and Quaternary samples through to the work of Ida Comaschi Caria (1911-1987) (Comaschi Caria 1959a, b, c, 1986; Comaschi Caria and Pastore 1959). This collection includes plants, invertebrates and vertebrates (mainly shark teeth) collected throughout Sardinia, but, in particular, in the Cagliari area and are currently housed in the Comaschi Caria's Collection.

The MDLCA's collections provide a complete overview of the geo-palaeontological heritage of Sardinia and include unique samples whit considerable scientific and historical value that may also be attractive to the general public. Unfortunately, available exhibition space within the Main Hall and the Lovisato's Hall is scarce and largely inadequate to highlight the geological and palaeontological richness of the entire collection (Figs. 7a and 8). Thankfully, a large portion of Neogene fossils collected in the environs of Cagliari are currently on display at the museum. Among marine vertebrates, numerous specimens of shark teeth belonging to several taxa could potentially draw visitors. This collection includes teeth of the giant Otodus megalodon (Agassiz 1843) (Fig. 7e), which were retrieved in the Calcari di Cagliari Fm. and Argille di Fangario Fm. (Comaschi Caria 1973). Reptiles are represented by crocodile and turtle fossils which are scientifically and historically important (Gennari 1868; Capellini 1890a, b; Portis 1901a; Comaschi Caria 1959a). These include a partial skull and a few osteoderms of the crocodile Tomistoma calaritanum Capellini 1890a, b, which were found in 1860 at Piazza d'Armi in the city. The original fossils (Fig. 7b), damaged during the Second World War, are located in the showcase dedicated to the Miocene reptiles, while a resin cast of the crocodile skull restored by Giovanni 
Fig. 5 a Alberto Lamarmora (1789-1863) in a drawing by G. Cominotti (after Lamarmora 1857), b the Pleistocene bone breccias of Monreale di Bonaria in 1831 (Cagliari), drawing by G. Cominotti (after Lamarmora 1857), c vertebrate remains and lithotypes collected by Lamarmora at Monreale di Bonaria (Lamarmora's Collection, MDLCA)

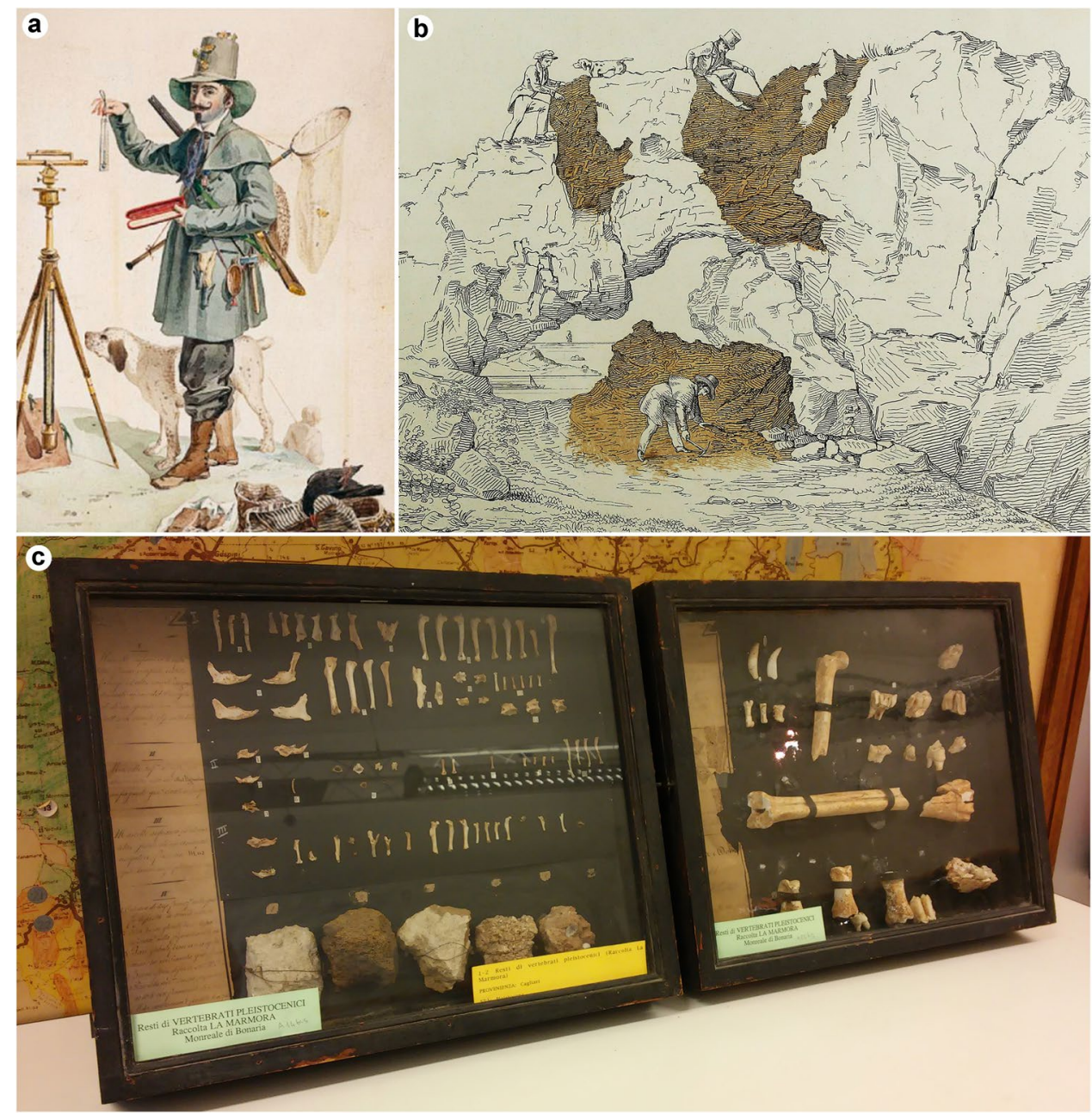

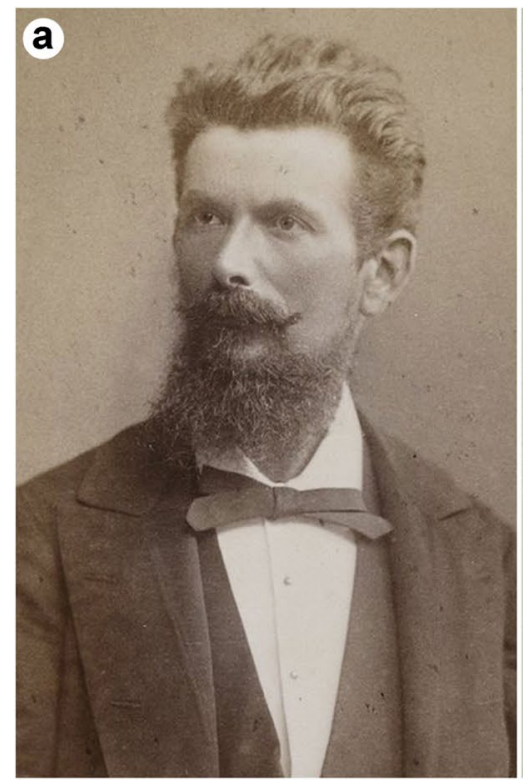

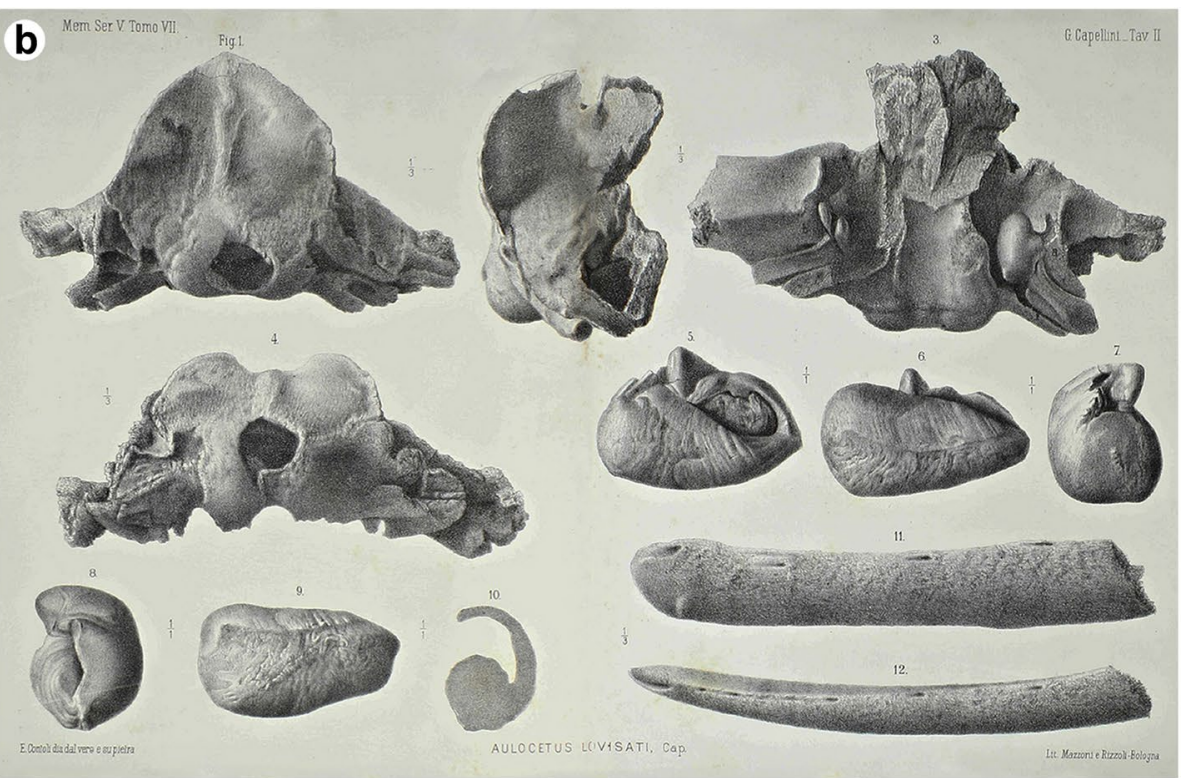

Fig. 6 a Domenico Lovisato (1842-1916), b fossils of a Miocene whale collected by Lovisato in the San Michele neighbourhood in 1886 (modified after Capellini 1899) 
Fig. 7 The Museo Sardo di Geologia e Paleontologia Domenico Lovisato and fossils from the Miocene of Cagliari exposed in its display cases: a the hall of the museum, b holotype of the crocodile Tomistoma calaritanum Capellini 1890a, b from Piazza d'Armi, $\mathbf{c}$ the echinoid Clypeaster altus (Klein 1734) from Colle San Michele, d plaster cast of the internal mould of the soft-shell turtle "Procyclanorbis sardus" Portis 1901b (now considered an indeterminate Pan-Trionychine) from Is Mirrionis neighbourhood, e some teeth of the giant shark Otodus megalodon (Agassiz 1843) from various neighbourhoods of Cagliari
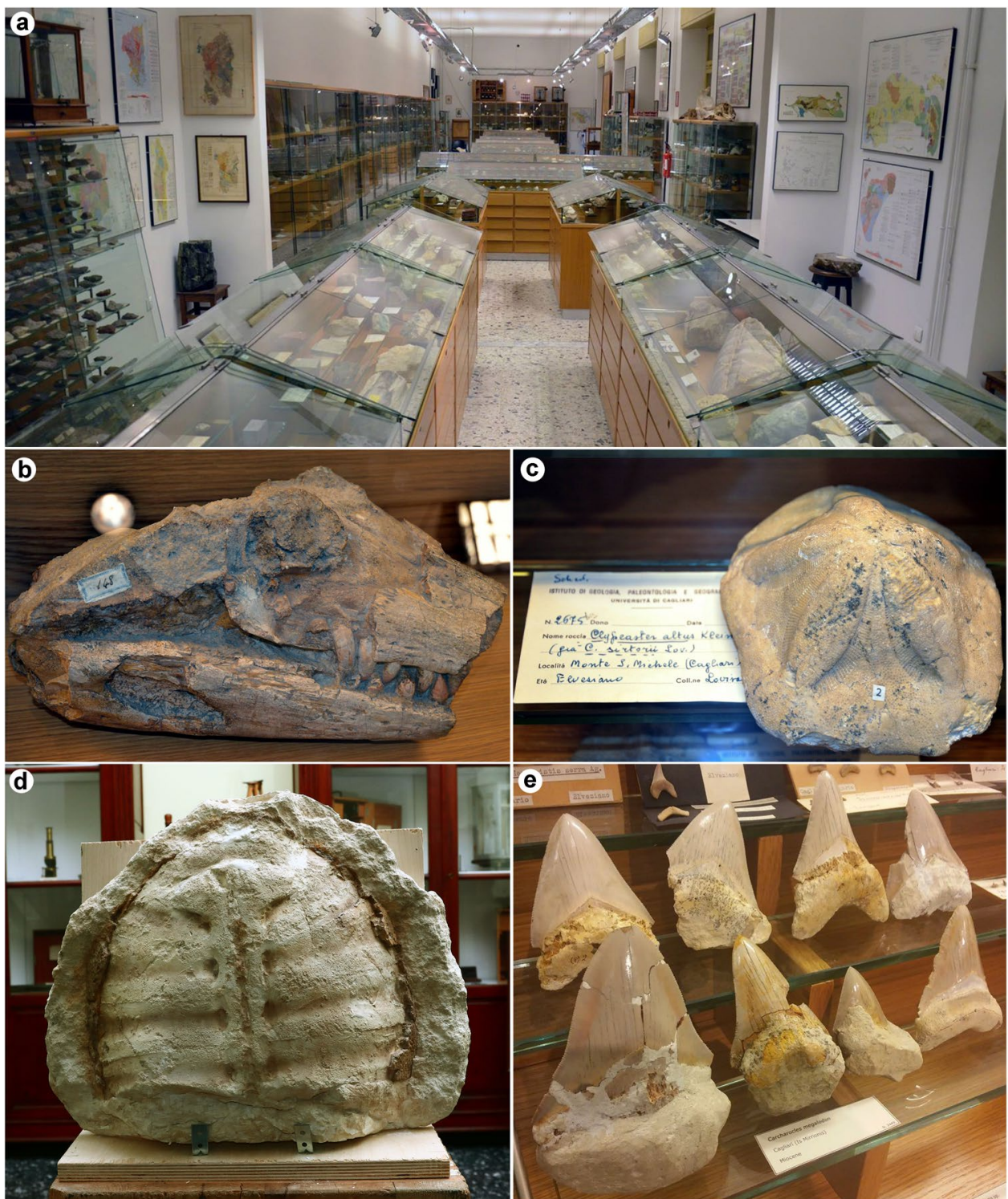

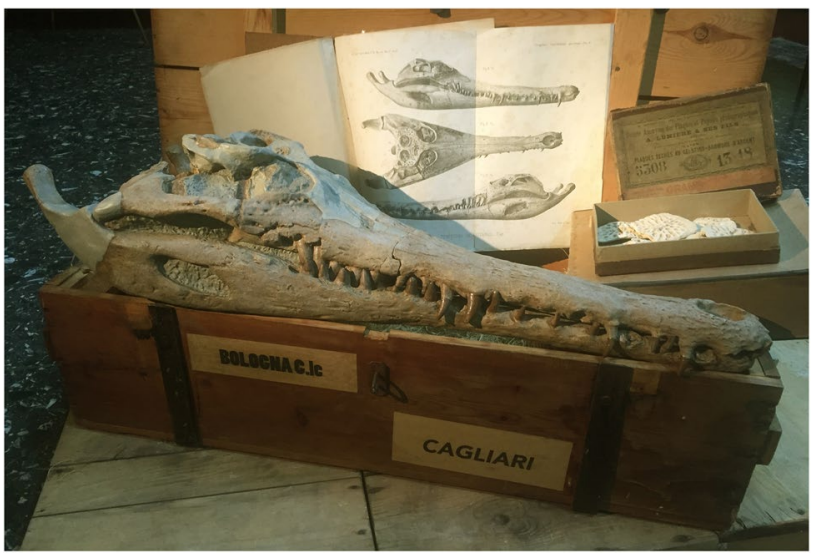

Fig. 8 Resin cast of the restored skull and plaster-casts of some osteoderms of the crocodile Tomistoma calaritanum Capellini 1890a, b, displayed with a copy of the original paper where the fossils have been first described
Capellini is exhibited in the Lovisato's Hall (Fig. 8). Two examples of soft-shell turtles (Pan-Trionychine indet.) from the Piazza D'Armi-Is Mirrionis area are also represented (Fig. 7d) (Portis 1901b; Comaschi Caria 1959a). Although some of the species housed in the collection are now considered taxonomically invalid (e.g. Rhinostodes lovisatoi Vigliarolo 1893, Palaeopython sardus Portis 1901a and Procyclanorbis sardus Portis 1901b), many still retain a significant historical value (Bianucci et al. 1994; Delfino et al. 2014; Georgalis et al. 2017; Zoboli et al. 2019).

While the MDLCA's current exhibition space is inadequate, the museum has the advantage of being centrally located in an accessible area of the city where several schools and University faculties are present. The central location of MDLCA offers an excellent meeting point for disseminating knowledge of Sardinian geological history and geoscience research. Added to this are the extensive 
Miocene sediments with their considerable fossil content that outcrop in the Sa Duchessa neighbourhood and surrounding areas (e.g. Is Mirrionis, Piazza D'Armi and Parco di Monte Claro) which present fossils in situ. These outcrops, adjacent to the museum, provide an excellent opportunity to develop an integrated, multi-location urban geotourism attraction for the city.

\section{Urban Geotourism Project}

In 2017, the University of Cagliari obtained funding for the "Coccodrilli, squali e tartarughe: storie di fossili a Cagliari e nell'area urbana" project from the Italian Ministry of Education, University and Research (Ministero dell'Educazione, Università e Ricerca, MIUR).

The CST was a project proposed by the Faculty of Humanistic Studies (Facoltà di Studi Umanistici) and the Faculty of Sciences (Facoltà di Scienze) of the University of Cagliari. The Department of History, Cultural Heritage and Territory (Dipartimento di Storia, Beni culturali e Territorio, now Dipartimento di Lettere, lingue e Beni Culturali) compiled a history of the palaeontological research around Cagliari and across the island. The research focused on biographical details of the leading geologists and palaeontologists, as well as detailed critical analysis of their published works, their travel diaries and private correspondence. These sources gave further historical context to the times in which these pioneering scientists worked. Additionally, during the historical research, a large number of original documents was digitised and made publicly available as part of the project "Sardoa digital library". In tandem, the Department of Chemical and Geological Sciences (Dipartimento di Scienze Chimiche e Geologiche) conducted several new surveys throughout the urban area to assess the potential of sites for geotourism given their historical significance. These surveys focussed on acquiring new geological and palaeontological samples. These data are available to both students and researchers. In addition to university researchers, the project included partners from industry (Sardinia Geomining Park) as well as local high schools. Students from Cagliari, Tortolì, Iglesias and Isili assisted in carrying out the project, providing invaluable support for this project thanks to the application of the new technologies and languages. For example, e-books, applications on smartphones and tablets have been created to make the project available to a very large audience (Fig. 9). The Sardinia Geomining Park was particularly helpful in the production of a video-story of the entire experience.

\section{Geoitinerary}

The combined historical and scientific research facilitated the creation of a geoitinerary divided into three routes (Fig. 10): (1st) MDLCA - Piazza d'Armi - Buoncammino - Giardini Pubblici - old town (about $2.2 \mathrm{~km} \mathrm{long),}$ (2nd) MDLCA - Piazza d'Armi - Buoncammino - Orto
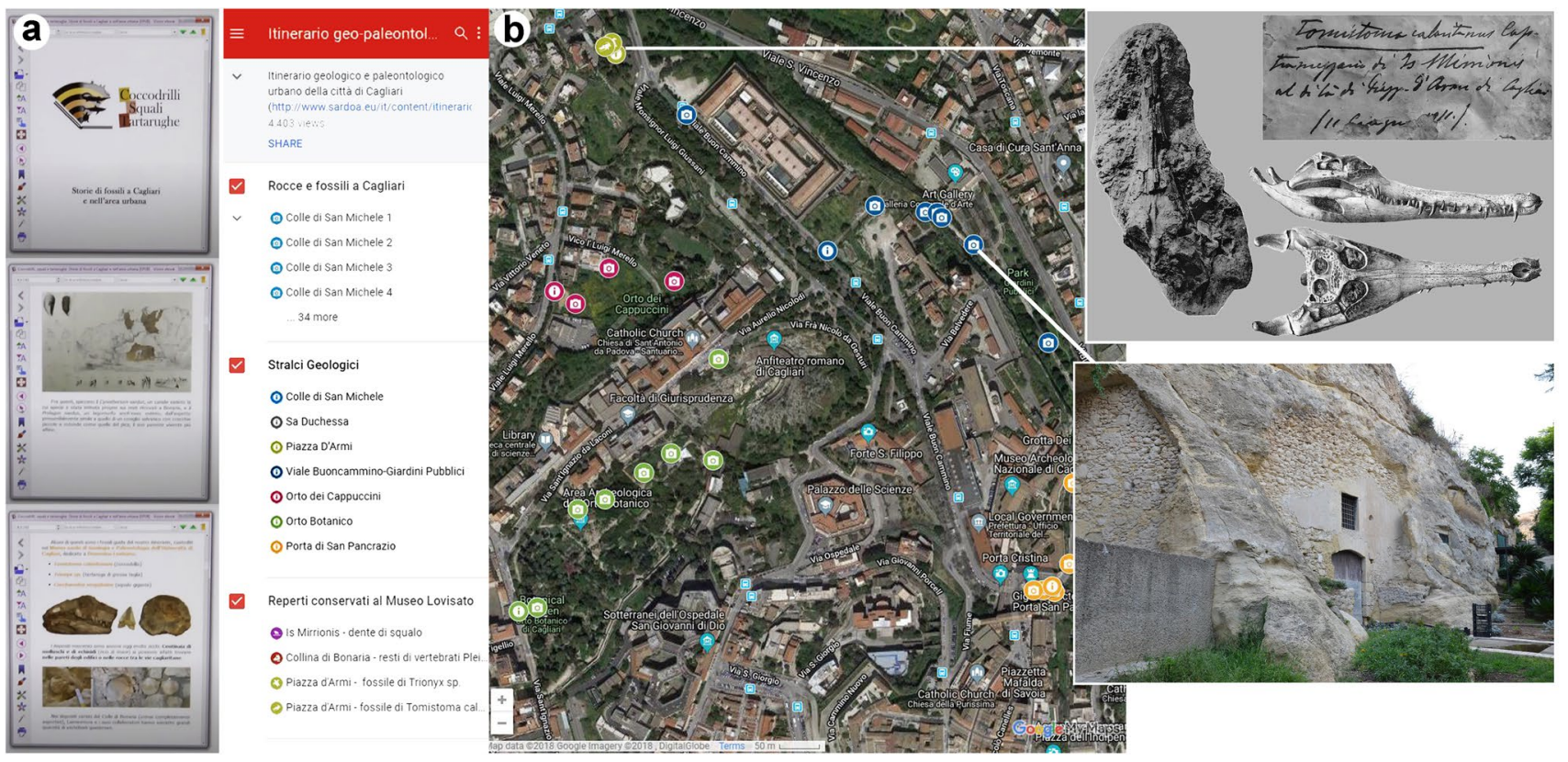

Fig. 9 a The CST e-book made by students from different Sardinia's high schools (courtesy of Parco Geominerario Storico ed Ambientale della Sardegna), b the urban geological heritage of Cagliari in an interactive map realised to the project. The map reported a short stretch of the 1st route (modified after Romo Mulas 2018). Please note: the website is currently unavailable 
Fig. 10 The routes and the main stops of the geoitinerary. Route 1: a MDLCA, b parking area (Sa Duchessa), c Piazza d'Armi/Is Mirrionis, $\mathbf{d}$ former Cagliari prison (Carcere di Buoncammino), e Public Gardens (Giardini Pubblici), $\mathbf{f}$ Porta S'Avanzada (a gate of the Cagliari's old town, Castello neighbourhood), g panoramic view, $\mathbf{h}$ Bastion of in Saint Remy. Route 2: a MDLCA, b parking area (Sa Duchessa), c Piazza d'Armi/Is Mirrionis, d former Cagliari prison (Carcere di Buoncammino), e Botanical Garden, f Garden of the Capuchins, $\mathbf{g}$ Tuvixeddu Archaeological Park, h nunnery "Curia delle Ancelle della Sacra Famiglia" (Sant'Avendrace neighbourhood), i Colle San Michele. Route 3: a bus stop, b panoramic view on "The Devil's Saddle" (Sella del Diavolo), c Cala Fighera, d Calamosca, e Sant'Elias's Lighthouse (Faro Sant'Elia). On the bottom right, the areas of the three routes
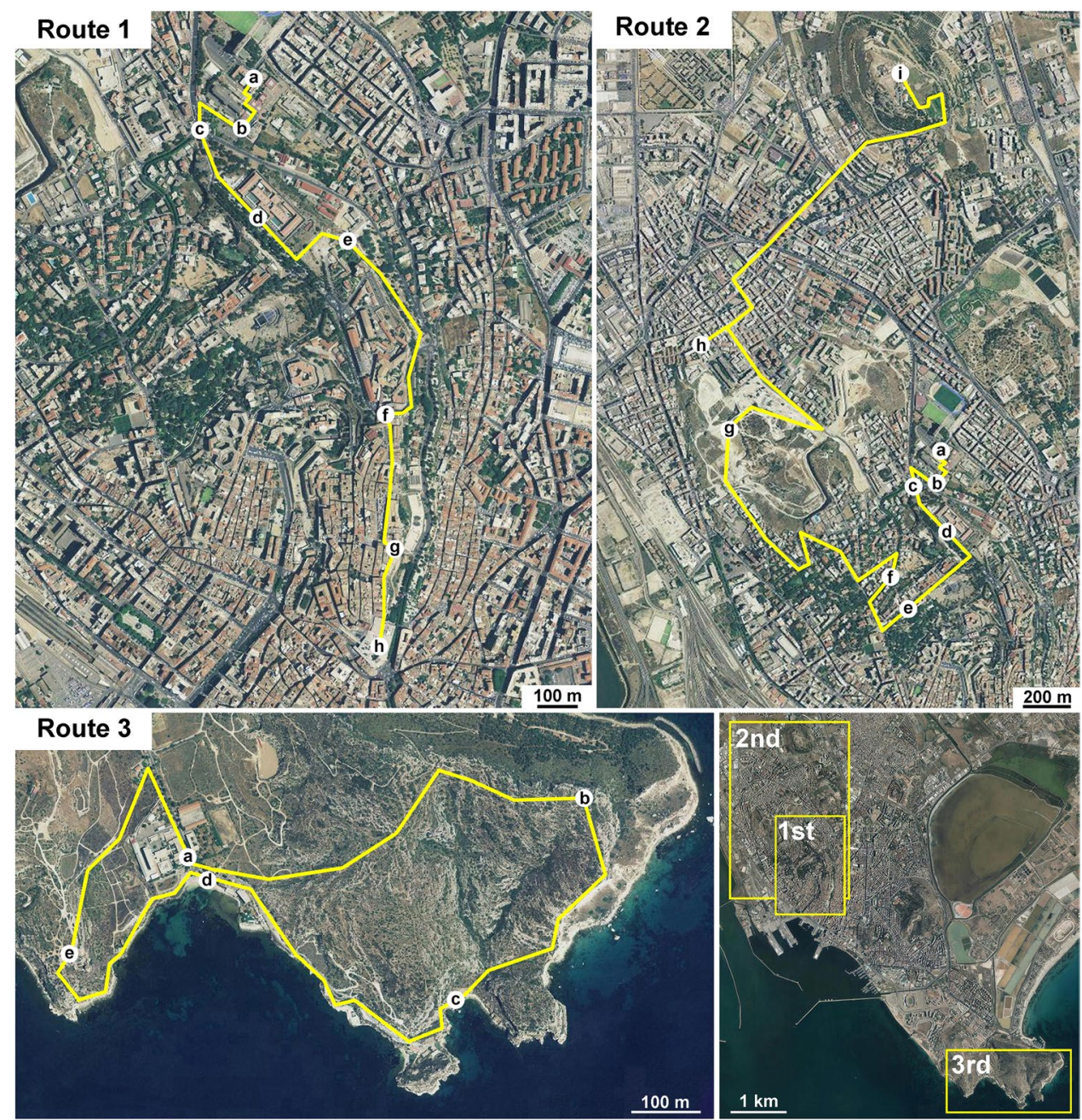

Botanico - Orto dei Cappuccini - Tuvumannu/Tuvixeddu - Sant'Avendrace - Colle San Michele (about 7 km long), (3rd) MDLCA - Capo Sant'Elia (about $5 \mathrm{~km}$ long). The first two are walking paths starting from MDLCA. The third route requires use of public transport from the city centre to the Calamosca beach resort.

Route 1 This route starts after the visit at MDLCA and continues to the parking area of the Department of History, Cultural Heritage and Territory (Sa Duchessa neighbourhood) in which the "Pietra Cantone" and "Tramezzario" lithofacies are visible (Fig. 11a). The second stop is Piazza d'Armi in which the fossils of the crocodile Tomistoma calaritanum were found (Gennari 1868) (Fig. 8). It then continues along Viale Buoncammino, skirting the former Cagliari prison. In the external walls of this building, it is possible to see mollusc and echinoid within numerous stone bricks of "Pietra Forte" limestone (Fig. 11d). The route continues to the public gardens (Giardini Pubblici); there are extensive carbonate outcrops characterised by different lithofacies, as well as rich invertebrate fossil content. Several fault lines cutting this carbonate succession are also visible. The route ends at Cagliari's old town (Castello neighbourhood). Here, different lithologies can be seen in the ancient buildings and town defences. From this point, there are views over a considerable portion of the modern city, as well as the hills leading to the coast. From this point, it is also possible to access to other museums, for example, the National Archaeological Museum (Museo Archeologico Nazionale di Cagliari), the National Picture Gallery of Cagliari (Pinacoteca Nazionale di Cagliari) and the collection of anatomical waxes (Museo delle Cere Anatomiche C. Susini).

Route 2 The first four stops of this route are the same as route 1. It diverges from route 1 at the former Cagliari prison and proceeds to the Botanical Garden (Orto Botanico di Cagliari) and at Garden of the Capuchins (Orto dei Cappuccini). In these two gardens, it is possible to see the interaction between the Miocene substrate and anthropic activities during previous centuries. The Garden of the Capuchins (Fig. 11c) contains several quarries initially excavates in the first or second century AD for the construction of 
Fig. 11 a Groove marks in an outcrop, base of debris flows at the "Pietra Cantone" -

"Tramezzario" lithofacies, Calcari di Cagliari Fm. (Sa Duchessa neighbourhood, routes 1 and 2-2nd stop), b "Pietra Cantone" - "Tramezzario" boundary, Calcari di Cagliari Fm. (Colle San Michele, route 2-9th stop), c Miocene succession at the Garden of the Capuchins (Orto dei Cappuccini, route 2-6th stop), Calcari di Cagliari Fm., d external mould of a Glycymerididae bivalve in a stone brick on the wall of the former Cagliari prison (Carcere di Buoncammino, routes 1 and 2-4th stop), "Pietra Forte" lithofacies (Calcari di Cagliari Fm.)
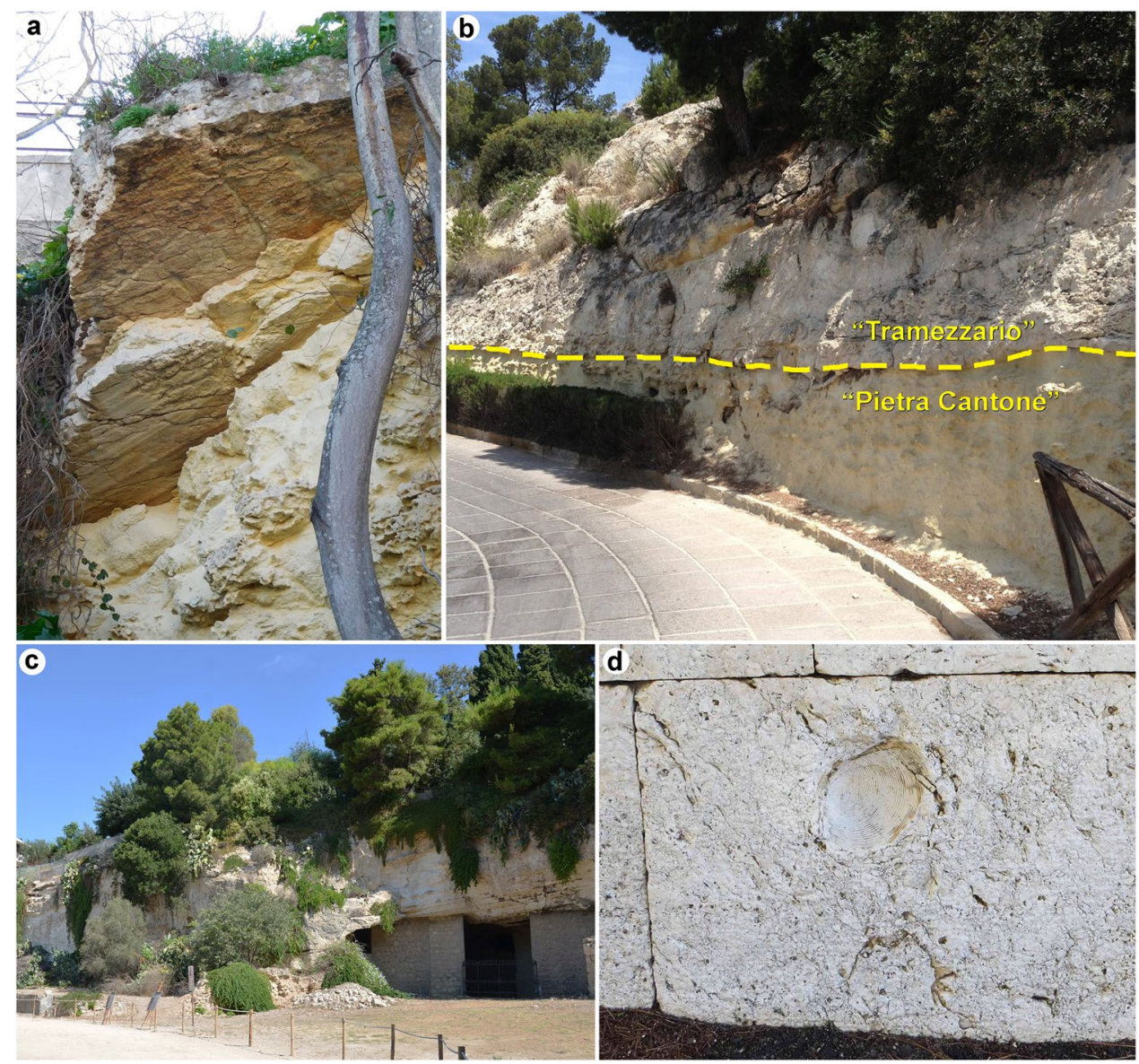

the Amphitheatre of Cagliari. The route continues to the Tuvixeddu Archaeological Park (Parco Archeologico di Tuvixeddu) where the largest Phoenician-Punic necropolis in the Mediterranean area was built. Crocodile teeth and cetacean remains were collected by Lovisato in the Tuvumannu/Tuvixeddu locale (Vigliarolo 1893; Del Vecchio 1921). The penultimate stop on route 2 is the private garden of the nunnery at Sant'Avendrace (Curia delle Ancelle della Sacra Famiglia) where a fossil of a marine turtle is set in a fountain (Fig. 12a). The fossil was found within the garden during the construction of a well in the 1950s (Comaschi Caria 1959a). The route ends at Colle San Michele, one of the most historically important hills of Cagliari where the castle of San Michele stands. This hill is also known for the discovery of the fossil remains of two whales (Capellini 1899) (Fig. 6b). At this stop, it is possible to view the urban area of Cagliari and view the Miocene marine succession outcrops rich in palaeontological content (Fig. 11b).

Route 3 This route unfolds entirely in the Miocene substrate; it is located on the southern outskirts of Cagliari, at Capo Sant'Elia. It is easily accessible by public transport starting at MDLCA. The entire urban area and the Golfo degli Angeli are visible from Monte Sant'Elia in which are present archaeological sites and representative natural monuments, such as the Sella del Diavolo ("The Devil's Saddle"). Along the route, beaches at Cala Fighera and Calamosca can be visited. At the latter, there are fossiliferous sediments of the Tyrrhenian Stage present and highly bioturbated Miocene strata are also visible. The route ends at the Sant'Elia's Lighthouse (Faro Sant'Elia) from which it is possible to return to the bus stop to the city.

\section{Final Considerations}

The environs of Cagliari undoubtedly have a rich archaeological, historical and natural heritage that has attracted increasing tourist numbers in the recent past. In addition to the old town and the built heritage therein, there is also a large number of museums. Among these, the Sardinian Geology and Palaeontology Museum of the University of Cagliari represents a unicum and significant tourism resource for the city. While exhibition space is inadequate, the museum curates a rich and varied geological and palaeontological heritage of historic and scientific values. This heritage, represented also by a large number of fossils collected in the Cagliari area, is the focus of the CST project, 
Fig. 12 a Internal mould of a Miocene cheloniid set in a fountain inside the garden of the nunnery "Curia delle Ancelle della Sacra Famiglia" (Sant'Avendrace, route 2-8th stop), b limestone outcrop (Calcari di Cagliari Fm.) at the Porta S'Avanzada (a gate of the Cagliari's old town, route $1-6$ th stop), in the square a large shell of an undetermined Pectinidae

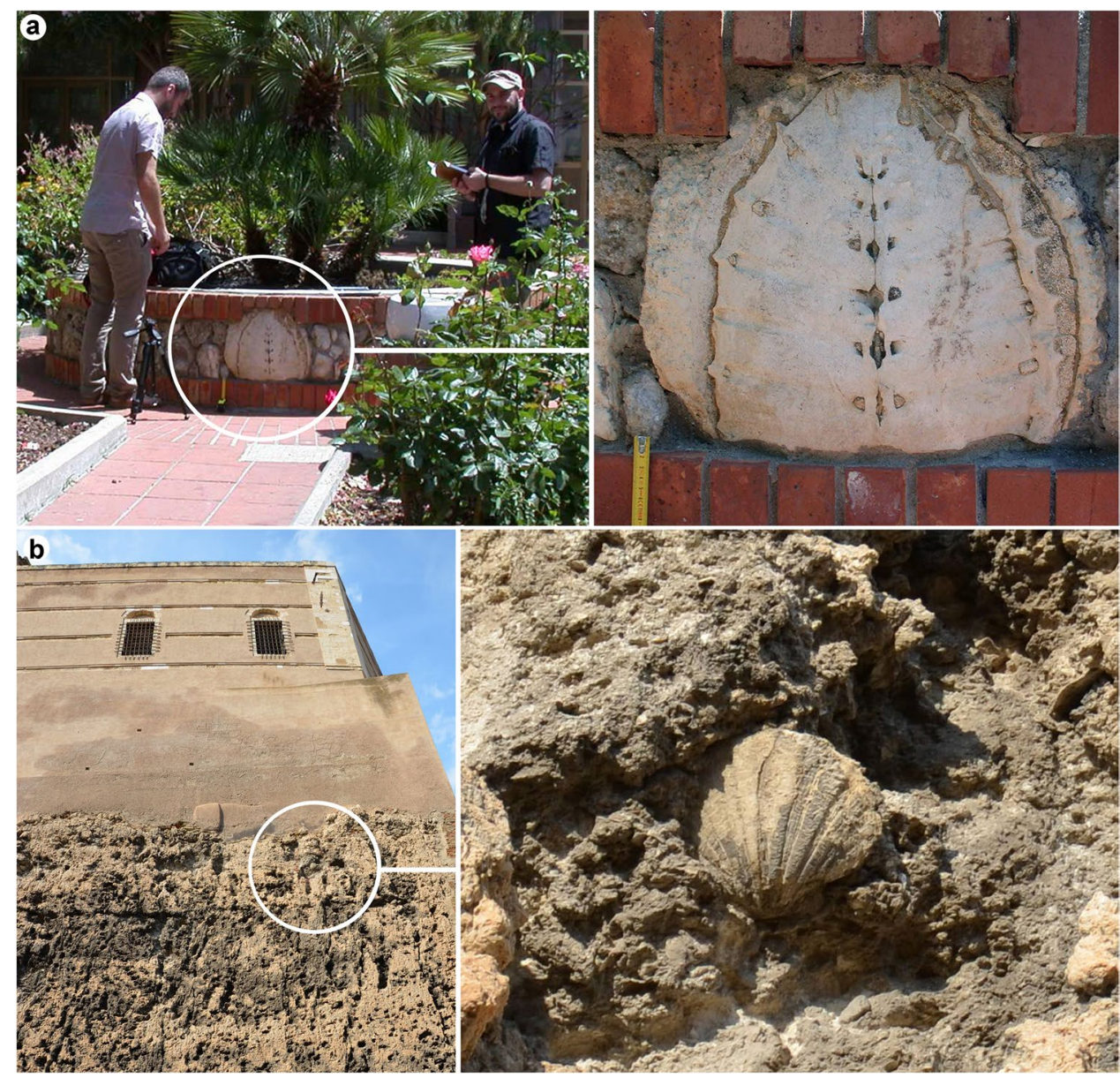

which aims to communicate geoscientific research for educational and tourism purposes. The CST project integrated scientific and historical data providing for the first time a considered overview of the urban geoheritage of Cagliari. For the first time, collaboration and complex knowledge transfer among high school students, researchers and public institutions have led to ideate an urban geoitinerary in Sardinia. The geoitinerary routes were planned with both tourists, students and amateur geologists or palaeontologists in mind with a view to revealing the rich geo-palaeontological heritage. However, this is only an example of the considerable geotourist potential of this urban area. In our opinion, this project has massive potential for raising awareness of local natural history. We believe the approach taken here is a simple, straightforward and affordable means of promoting and preserving geoheritage in other regions.

Acknowledgements D.Z. was supported by grants P.O.R. Sardegna F.S.E. 2014-2020-Asse III Istruzione e Formazione, Obiettivo Tematico: 10, Obiettivo Specifico: 10.5, Azione dell'accordo di Partenariato: 10.5.12 "Avviso di chiamata per il finanziamento di Progetti di ricerca-Anno 2017”. G.L.P. was supported by the Università di Cagliari CAR Project, "Paleobiodiversità: strumento di base in biostratigrafia, in paleoecologia e nella valorizzazione dei beni culturali
Geo-Paleontologici”. We thank all the participants to the project CST, especially the teachers and the students of Liceo Classico Scientifico "Euclide" (Cagliari), Liceo Scientifico delle Scienze Applicate (Tortolì), Liceo Scientifico "G. Asproni” (Iglesias) and Liceo Scientifico Statale "Pitagora" (Isili). We also thank the Consorzio del Parco Geominerario Storico e Ambientale della Sardegna. We are grateful to Dr Robert O'Hara of Teagasc Agriculture and Food Develpment Authority, Ireland, for the English use and editing.

Funding Open access funding provided by Università degli Studi di Cagliari within the CRUI-CARE Agreement. Thanks are also due to the Regione Autonoma della Sardegna project for the financial support in the frame of "Il viaggio naturalistico nella Sardegna tra Sette e Ottocento attraverso la D-library Sardoa-la Sardegna e le scienze", MIUR Project call 2017 "Coccodrilli, squali e tartarughe: storie di fossili a Cagliari e nell'area urbana”.

Open Access This article is licensed under a Creative Commons Attribution 4.0 International License, which permits use, sharing, adaptation, distribution and reproduction in any medium or format, as long as you give appropriate credit to the original author(s) and the source, provide a link to the Creative Commons licence, and indicate if changes were made. The images or other third party material in this article are included in the article's Creative Commons licence, unless indicated otherwise in a credit line to the material. If material is not included in the article's Creative Commons licence and your intended use is not permitted by statutory regulation or exceeds the permitted use, you will 
need to obtain permission directly from the copyright holder. To view a copy of this licence, visit http://creativecommons.org/licenses/by/4.0/.

\section{References}

Barca S, Melis E, Annino E, Cincotti F, Ulzega A, Orrù P, Pintus C (2005) Note Illustrative della Carta Geologica d'Italia alla scala 1:50.000. In: Foglio 557 “Cagliari”. Servizio Geologico d'Italia, Regione Autonoma della Sardegna, S.EL.CA, Firenze

Bianucci G, Landini W, Varola A (1994) New remains of Cetacea Odontocet from the "Pietra leccese" (Apulia, Italy). Bollettino Della Società Paleontologica Italiana 33(2):215-230

Berrocal-Casero M, Arribas M, Joaquín Moratalla J (2018) Didactic and divulgative resources of the Middle Triassic vertebrate tracksite of Los Arroturos (Province of Guadalajara, Spain). Geoheritage 10:375-384

Capellini G (1886) Cetacei e Sirenii fossili scoperti in Sardegna. Rendiconti Della Accademia Dei Lincei, Classe Di Scienze Fisiche e Matematiche 4(2):79-81

Capellini G (1890) Sul coccodrilliano garialoide (Tomistoma calaritanus) scoperto nella collina di Cagliari nel 1868. Rendiconti Della Reale Accademia Dei Lincei 4:149-151

Capellini G (1890) Sul coccodrilliano garialoide (Tomistoma calaritanus) scoperto nella collina di Cagliari nel MDCCCLXVIII. Atti Della Reale Accademia Lincei, Memorie Della Classe Di Scienze Fisiche, Matematiche e Naturali 6:507-533

Capellini G (1899) Balenottere mioceniche di San Michele presso Cagliari. Memorie Della Accademia Delle Scienze Dell'istituto Di Bologna 5(8):661-678

Cherchi A (1974) Appunti biostratigrafici sul Miocene della Sardegna (Italia). Mémoire Du Bureau De Recherches Géologiques Et Minières 78:433-445

Columbu S, Lisci C, Sitzia F, Buccellato G (2017) Physical-mechanical consolidation and protection of Miocenic limestone used on Mediterranean historical monuments: the case study of Pietra Cantone (southern Sardinia, Italy). Environ Earth Sci 76:148. https://doi.org/10.1007/s12665-017-6455-6

Comaschi Caria I (1958) Il Miocene in Sardegna. Bollettino Della Società Geologica Italiana 77(1):183-198

Comaschi Caria I (1959) Nuovi resti di cheloni nel Miocene della Sardegna. Bollettino Della Società Geologica Italiana 78:37-44

Comaschi Caria I (1959) Nuovi resti di Prolagus in Sardegna. Rendiconti Del Seminario Della Facoltà Di Scienze Dell'università Di Cagliari 29:75-84

Comaschi Caria I (1959) Il Miocene in Sardegna. Bollettino Della Società Geologica Italiana 77:183-198

Comaschi Caria I (1972) I pettinidi del Miocene della Sardegna. Stabilimento Tipografico Editoriale Fossataro, Cagliari

Comaschi Caria I (1973) I pesci del Miocene della Sardegna. Stabilimento Tipografico Editoriale Fossataro, Cagliari

Comaschi Caria I (1979) Storia e vicende del Museo geo-paleontologico "Domenico Lovisato" dell’Università di Cagliari. Litotipografia Il Torchio, Cagliari

Comaschi Caria I (1986) Animali e piante fossili della Sardegna, Terza edizione ampliata e con un guida breve allo studio della Paleontologia. Edizioni della Torre, Cagliari

Comaschi Caria I, Pastore R (1959) Fauna del Tirreniano di Margine Rosso (Quartu Sant'Elena) e di Calamosca (Cagliari). Rendiconti Dei Seminari Della Facoltà Di Scienze Dell'università Di Cagliari 29:1-10

Delfino M, Zoboli D, Carnevale G, Pillola GL (2014) The rediscovered holotype of Palaeopython sardus Portis, 1901 from the Miocene of Sardinia belongs to a fish, not a snake. Bollettino Della Società Paleontologica Italiana 53:89-92

Del Lama EA, de La Corte Bacci D, Martins L, da Glória Motta Garcia M, Kazumi Dehira L (2015) Urban Geotourism and the Old Centre of São Paulo City, Brazil. Geoheritage 7:147-164

Del Vecchio C (1921) Su alcuni denti di Tomistoma (Crocodilia) dell'Oligocene di Visone presso Acqui. Atti Della Società Italiana Di Scienze Naturali 60:419-431

Gandolfi R, Porcu A (1967) Contributo alla conoscenza delle microfacies mioceniche delle colline di Cagliari (Sardegna). Riv Ital Paleontol Stratigr 73:313-348

Gennari P (1868) Di un coccodrillo fossile nel terreno pliocenico di Cagliari. Atti Dell'accademia Dei Fisiocritici Di Siena 2:127-129

Georgalis GL, Zoboli D, Pillola GL, Delfino M (2017) A revision of the trionychid turtle Procyclanorbis sardus Portis, 1901 from the late Miocene of Sardinia (Italy). Annales De Paléontologie 103:127-134. https://doi.org/10.1016/j.annpal.2017.04.002

Giordano E, Giardino M, Perotti L, Ghiraldi L, Palomba M (2016) Following the tracks of Charlemagne in the Cottian Alps. The Cultural and Geological Heritage of the Franks Trail (Susa Valley, Piemonte, NW Italy). Geoheritage 8:293-300

Hose TA (2000) European "geotourism" - geological interpretation and geoconservation promotion for tourists. In: Barettino D, Wimbledon WAP, Gallego E (eds) Geological heritage: its conservation and management, Madrid, pp 127-146

Hose TA (2008) Towards a history of Geotourism: definitions, antecedents, and the future. In: Burek CV, Prosser CD (eds) The history of geoconservation, vol 300, Geological Society Special Publication, pp 37-60

Issel A (1914) Lembi fossilferi quaternari e recenti nella Sardegna meridionale. Accademia Nazionale Dei Lincei 5(23):759-770

Lamarmora A (1857) Voyage en Sardaigne, III partie, description géologique. Delaforest, Turin

Leone F, Pontillo C, Spano C (1992) Benthic paleocommunities of the middle-upper Miocene lithostratigraphic units from the Cagliari hills. IGCP Project n 275(5):151-158

Liso IS, Chieco M, Fiore A, Pisano L, Parise M (2020) Underground geosites and caving speleotourism: some considerations, from a case study in Southern Italy. Geoheritage 12:13. https://doi.org/ 10.1007/s12371-020-00424-Z

Lovisato D (1892) Nuovi resti di coccodrilliano fossile nel Miocene di Nurri. Atti Della Regia Accademia Dei Lincei 1:436-439

Lovisato D (1902) Le specie fossili finora trovate nel calcare compatto di Bonaria e di San Bartolomeo. Tipo-Litografia Commerciale, Cagliari

Lovisato D (1915) Undicesimo contributo echinodermico con nuove specie di Clypeaster del Miocene medio sardo. Bollettino Del Regio Comitato Geologico D'italia 44(3):180-193

Lovisato D (1915b) Dodicesimo contributo echinodermico con 12 specie nuove di Clypeaster del Miocene medio ed inferiore di Sardegna. Bollettino della Società Geologica Italiana 34: 470-504

Magliulo P, Di Lisio A, Sisto M, Valente A (2020) Geotouristic enhancement of high-quality wine production areas: examples from Sannio and Irpinia Landscapes (Campania Region, Southern Italy). Geoheritage 12:18. https://doi.org/10.1007/ s12371-020-00429-8

Pecorini G, Pomesano Cherchi A (1969) Ricerche geologiche e biostratigrafiche sul Campidano meridionale (Sardegna). Memorie Della Società Geologica Italiana 8:421-451

Portis A (1901a) Il Palaeopython sardus Port. Nuovo pitonide del Miocene medio della Sardegna. Bollettino Della Società Geologica Italiana 20:247-253

Portis A (1901b) Il Procyclanorbis sardus Port., nuovo trionychide fossile della Sardegna. Bollettino Della Società Geologica Italiana 20:51-79 
Romo Mulas RA (2018) I grandi studiosi della geologia di Cagliari: dai dati storico-scientifici alla divulgazione ICT. Unpublished thesis, University of Cagliari

Sanciu L, Zoboli D (2018) Il Geosito paleontologico "Cava Duidduru" e il Museo P.AR.C. di Genoni: un esempio di ripristino e valorizzazione di un bene geopaleontologico in Sardegna. Museologia Scientifica, Nuova Serie 12:42-47

Santangelo N, Romano P, Santo A (2015) Geo-itineraries in the Cilento Vallo di Diano Geopark: A Tool for Tourism Development in Southern Italy. Geoheritage 7:319-335

Spano C, Barca S (2002) Ecobiostratigraphic, lithostratigraphic, depositional and synthemic setting of Cenozoic units in Southern Sardinia (Italy). Bollettino Della Società Geologica Italiana 121:19-34

Todaro S (2019) The potential geosite of the "Libeccio Antico" quarries: a sedimentological and stratigraphic characterisation of ornamental stone from Mt Cocuccio, Custonaci Marble District, Sicily. Geoheritage 11:809-820. https://doi.org/10.1007/ s12371-018-0337-5

Ulzega A, Ozer A (1980) Excursion-Table Ronde sur le Tyrrhénien de Sardaigne. "INQUA - Commission des Lignes de Rivage", Cagliari 21-28 Avril 1980, 87
Venturini C, Mariotto PF (2020) Geoheritage promotion through an interactive exhibition: a case study from the Carnic Alps, NE Italy. Geoheritage 11:459-469. https://doi.org/10.1007/ s12371-018-0299-7

Vigliarolo G (1893) Dei generi Micropteron, Dioplodon e Rhinostodes e di una nuova specie fossile di Rhinostodes scoperta nel calcare elveziano di Cagliari. Atti Della Reale Accademia Delle Scienze Fisiche e Matematiche Di Napoli 6:1-37

Zoboli D, Pillola GL (2016) Quaternary mammal fauna from "Surconis", Bolotana (Sardinia, Italy). Bollettino Della Società Paleontologica Italiana 55:193-203

Zoboli D, Pillola GL (2017) Upper Pleistocene mammal assemblage from Su Concali Quarry (Samatzai, southern Sardinia, Italy). Rivista Italiana di Paleontologia e Stratigrafia 123(2):243-254. https://doi.org/10.13130/2039-4942/8371

Zoboli D, Sanciu L, Pillola GL, Delfino M (2019) An overview of the crocodylian fossil record from Sardinia (Italy). Annales De Paléontologie 105:123-137. https://doi.org/10.1016/j.annpal. 2019.05.001 